Click www.researchjournal.co.in/online/subdetail.html to purchase.

Volume 5 | Issue 2 | September, 2014 | 220-223 — e ISSN-2231-6434 |

International Research Journal of Agricultural Economics and Statistics

Visit Us - www.researchjournal.co.in DOI : 10.15740/HAS/IRJAES/5.2/220-223

\title{
Research Paper Comparative economics of Kharif and summer paddy production in Dhamtari district
}

\author{
A.K. DEWANGAN AND A.K. GAURAHA
}

See end of the paper for authors' affiliations

Correspondence to :

\section{A.K. DEWANGAN}

Department of Agricultural Economics, Indira Gandhi Krishi Vishwavidalaya, RAIPUR (C.G.) INDIA

Email:atuldwngn@gmail. com

Paper History :

Received : 31.05 .2014

Revised : 12.07.2014;

Accepted: 26.07 .2014
ABSTRACT : This study aimed to define the comparative economics of Kharif and summer paddy production in Dhamtari district of Chhattisgarh. The four villages were selected from two blocks namely, Rudri and Hatkeshar from Dhamtari block, Silouti and Joratrai from Kurud block to collect the required information on comparative economics of Kharif and summer production of paddy crop. The study is confined to paddy crop which is the major field crop of Chhattisgarh and it is popularly known as the "Rice bowl of India". The growers were classified as marginal ( $0-1.0 \mathrm{ha})$, small $(1.1<2.0 \mathrm{ha})$, medium $(2.1<4.0 \mathrm{ha})$ and large farmers (above $4 \mathrm{ha})$. The average cost of production per quintal of Kharif paddy was worked out to Rs. 581.61 and summer paddy was Rs. 497.93. The input-output ratio of Kharif paddy was worked out to 1:2.87 and for summer paddy was 1:2.55. The results of this study portray an encouraging picture of the current state of paddy production at farm level. A positive association between adoption rates of improved inputs and profitability of the new paddy technology was evident. High rate of adoption of HYVs of paddy was mainly due to the irrigation facilities and farmers willingness to increase the per unit productivity of land resources.

KEY WORDS : Economics, Production, Kharif paddy, Summer paddy

HOW TO CITE THIS PAPER : Dewangan, A.K. and Gaurala, A.K. (2014). Comparative economics of Kharif and summer paddy production in Dhamtari district. Internat. Res. J. Agric. Eco. \& Stat., 5 (2) : 220-223. 